\title{
RETROSPECTIVE STUDY ON ANGIOTENSIN-CONVERTING-ENZYME INHIBITORS TREATMENT
}

\author{
FLORIN MAGHIAR ${ }^{1}$, LAURA GRAT IELA VICAȘ ${ }^{2 *}$, ANDREEA ARDELEAN $^{3}$, ALIN $^{2}$ \\ TEUȘDEA ${ }^{4}$, OTILIA ANCA ȚICA ${ }^{1}$, CLAUDIU OROS $^{2}$, MARIANA EUGENIA MUREȘAN $^{5}$ \\ ${ }^{1}$ University of Oradea, Faculty of Medicine and Pharmacy, Medical Department, Oradea, Romania \\ ${ }^{2}$ University of Oradea, Faculty of Medicine and Pharmacy, Pharmacy Department, Oradea, Romania \\ 3 “Dr. G. Curteanu” Municipal Clinical Hospital, Oradea, Romania \\ ${ }^{4}$ University of Oradea, Faculty of Environmental Protection, Oradea, Romania \\ ${ }^{5}$ University of Oradea, Faculty of Medicine and Pharmacy, Preclinical Disciplines Department, Oradea, Romania
}

*corresponding author: laura.vicas@gmail.com

Manuscript received: September 2019

\begin{abstract}
The emergence of Captopril in 1977 marked the beginning of a new class of drugs for arterial hypertension: angiotensinconverting-enzyme-inhibitors (ACE inhibitors, ACE-I). This paper represents a retrospective study highlighting the risk/ benefit of using ACE inhibitors in patients. There were analysed the hospital records for 214 patients from the Municipal "Dr. G. Curteanu" Clinical Hospital, Oradea, Romania, in 2018 which were diagnosed with arterial hypertension and heart failure that were administered ACE inhibitors. The use of ACE inhibitors reduced the number of hospitalizations, therefore $86 \%$ of the patients didn't need to be hospitalized again in 2018. In $84 \%$ of the patients, the healing condition has been improved at hospital discharge; we can say that ACE inhibitors and associated treatment were helpful in reducing clinical symptoms.
\end{abstract}

\section{Rezumat}

Punerea pe piaţă a captoprilului în 1977 a marcat începutul unei noi clase de medicamente pentru hipertensiunea arterială: inhibitorii enzimei de conversie a angiotensinei (IECA). Această lucrare conţine un studiu retrospectiv în care a fost subliniat riscul/beneficiul utilizării IECA la pacienți. Au fost analizate înregistrările spitalului pentru 214 pacienți internați la Spitalul Clinic Municipal „Dr. G. Curteanu” din Oradea în 2018 care au fost diagnosticaţi cu hipertensiune arterială şi insuficiență cardiacă care se află în tratament cu IECA. Utilizarea IECA a redus numărul de spitalizări, prin urmare $86 \%$ dintre pacienți nu au avut nevoie să fie spitalizați din nou în 2018. La 84\% dintre pacienți, starea de sănătate a fost îmbunătătită la externarea din spital; se poate spune că IECA și tratamentul asociat au avut utilitate în reducerea simptomelor clinice.

Keywords: ACE inhibitors, retrospective study, arterial hypertension

\section{Introduction}

ACE inhibitors improve the quality of life and they reduce mortality associated with heart failure in myocardial infarction and arterial hypertension. ACE inhibitors are the first option in treating essential arterial hypertension and secondary arterial hypertension due to reno-vascular cause, with one exception: bilateral renal artery stenosis [1].

According to the BP-CARE (blood pressure care) study carried out in Central and Eastern European countries, blood pressure control in these countries is improper, especially in patients with high cardiovascular risk and it is associated with an increase in the risk of fatal and nonfatal cardiovascular events [20].

High Blood Pressure (HBP) is commonly associated with other cardiovascular risk factors like glucose intolerance and dyslipidaemia, which gives the importance to calculate the global cardiovascular risk in a hypertensive patient. This is accomplished by the SCORE system (Systematic Coronary Risk Evaluation) which allows us to estimate the risk of a fatal atherosclerotic event in the next 10 years in patients over 40 years of age $[2,3]$.

Left ventricular dysfunction can be asymptomatic, but it is considered a trigger to heart failure; two American classification systems by the American College of Cardiology/American Heart Association (ACC/AHA) and New York Heart Association (NYHA) for heart failure take this into account [5, 13, 17]. According to the $23^{\text {rd }}$ of May 2014 press release of the European Medicines Agency (EMA), the Committee for Medicinal Products for Human Use (CHMP) confirms the Pharmacovigilance Risk Assessment Committee (PRAC) recommendations for restricting the simultaneous administration of drugs that operate on the reninangiotensin system $[4,15]$.

It is not recommended to administer any drugs of this class at the same time, especially to patients with diabetes associated renal diseases (diabetic nephropathy). Therefore, the associations of the following are not recommended: ACE inhibitors and ARBs (angiotensin 
receptor blockers), ACE inhibitors and aliskiren; ARBs and aliskiren [15, 18, 22].

As before mentioned, CHMP confirms PRAC recommendations from EMA April 2014 after analysing data from cohort studies with various pre-existing cardiac or vascular diseases or with type 2 diabetes. These studies proved that simultaneous treatment with ACE inhibitors and ARBs, as compared with the treatment with just one of the two, is associated with a high risk of renal damage, low blood pressure or hyperkalaemia (high levels of potassium in serum). In patients without heart failure, no significant improvements have been noticed by double blocking the reninangiotensin system and the conclusion drawn was that the benefits outweigh the risks only in the case of a small group of patients with heart failure in which no other therapies are appropriate. This extensive re-evaluation of data on all the different agents that act on the Renin-Angiotensin (RA) system confirm the conclusion of a previous evaluation performed by EMA on drugs that contain aliskiren [15].

Based on current data, double blocking the RA system by using simultaneously angiotensin receptor blocker (ARBs), ACE-I or aliskiren is not recommended in any patient $[5,16,19]$.

Available data on efficacy show that double blocking the RA system does not bring significant benefits in the general public, also these benefits are registered on selected sub-populations. In patients with heart failure there is some evidence which shows that bringing a second agent that acts on the RA system would reduce hospitalization cases [15, 17]. In the case of any drug, it is beneficial to have maximum efficacy and a low risk. By benefits we mean: physical and chemical stability of the molecule; numerous and varied uses (especially in hard to treat or rare pathologies); high selectivity; high potency; ease of replacement; pregnancy and breastfeeding safe; diversity in pharmaceutical formulation; resistant to stomach acid; low impact of diet; low effect on day to day activities (driving, precision work); compatibility with as many excipients as possible; good absorption and bioavailability; useful and advantageous half-life; efficient passing through to the necessary tissue; optimal hydrophylic-lipophylic balance; being synthetized in necessary quantities. The results of the drug therapy are monitored across clinical trials and the benefitrisk ratio is analysed. Pharmacovigilance bulletins are extremely important in this regard [22].

\section{Materials and Methods}

The aim of this study was to identify the patients hospitalized in the Cardiology department of the "Dr. G. Curteanu" Municipal Clinical Hospital, Oradea, Romania, who were under therapy with ACE-I; underlining the demographics of these patients, global cardiovascular risk and associated pathologies, identifying drugs associated with ACE-I; possible side effects to ACE-I and patient status upon check out.

These patients have been chosen because HBP at an individual level does not represent a hospitalization criteria, as patients are usually admitted for congestive heart failure $(\mathrm{CHF})$ or associated pathologies. There were also included patients with NYHA II left ventricular failure (LVF) because it's a precursor to heart failure. Exclusion criteria: secondary HBP and HBP class I. Data was gathered by analysing medical records from the hospital archives.

In 2018 in the Cardiology department of the "Dr. G. Curteanu" Municipal Clinical Hospital, Oradea, Romania, there were 770 patients; among these, 214 had HBP (class II and III) and NYHA II left ventricular failure or congestive heart failure under ACE-I therapy. They were included in the current study.

Statistical analysis. The design of the experiment for the cardiovascular risk and content validity ratio $(\mathrm{CvR})$ parameters included two non-parametric statistical analysis tests: repeated measures two samples comparison (sign and Wilcoxon signed-rank test, $\mathrm{p}=0.05$ ) and two-sample Kolmogorov-Smirnov test for comparison of two distributions $(\mathrm{p}=0.05)$. The non-parametric statistical analysis was performed with the Minitab 19 (Minitab Inc., Coventry CV3 2TE, United Kingdom) statistical software.

\section{Results and Discussion}

For achieving the goals, a retrospective observational study of ACE-I therapy in HBP and left ventricular failure or congestive heart failure was performed on patients hospitalised in 2018. From these 214 patients, 116 were women $(54.20 \%)$ and 98 were men $(45.80 \%)$. 120 patients $(56.07 \%)$ came from the rural environment and $94(43.93 \%)$ came from the urban area.

The average age of the patients was 65.28 years, the youngest being 38 and the oldest 87 . We had 2 male patients between 31 and 40, representing 1\%,16 patients between 41 and 50 (7\%) from which 9 female and 7 males; between 51 and 60 years there were 69 patients (32\%) from which 39 females and 30 males; between 61 and 70 , we had 49 patients (23\%) from which 21 females and 28 males and above 71 we had 78 patients $(36 \%)$ from which 47 were females and 31 males. To analyse the data correctly we made an evaluation of the age distribution of the patients and we distributed the patients on age groups according to gender. Congestive heart failure ( $\mathrm{CHF}$ ) associated with $\mathrm{HBP}$ was present in $64.95 \%$ of the patients, numbering 139 cases and left ventricular failure was present in $35.05 \%$ of the patients, numbering 75 cases.

To establish the global cardiovascular risk it was used the SCORE diagram which calculates the death risk at 10 years. We noticed that $47.19 \%$ (101 patients -62 females and 39 males) have a global cardiovascular risk of death at 10 years higher or equal to $5 \%$. This 
FARMACIA, 2020, Vol. 68, 1

additional cardiovascular risk (high and very high) makes these two types of patients extremely important, transforming it into the target for treatment and prevention. $5.14 \%$ or 11 patients (7 women and 4 men) had an average additional cardiovascular risk. The cardiovascular risk values were organized in age classes for each gender factor level (women and men) as described in Figure 1. Furthermore, the proportions (\%) from the total number of analysed cases are presented in Figure 2. From both figures, it can be noticed that the women between 31 and 40 years old have no risk of cardiovascular risk of death. However, in the rest of age classes, exclusive the $61-70$ years old, women had greater values of cardiovascular risk than men, as can be seen in the dominance diagram (Figures 3 and 4). More than that, 102 patients (47 females and 55 males) or $47.66 \%$ had a risk bigger or equal to $10 \%$. These patients with a high risk were mainly men, numbering 55 which represents $25.7 \%$.

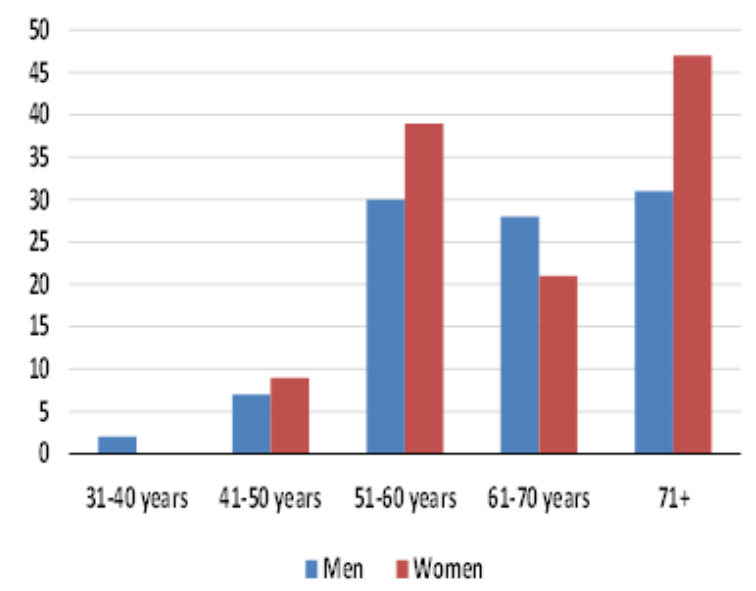

Figure 1.

Values of cardiovascular risk over the age classes

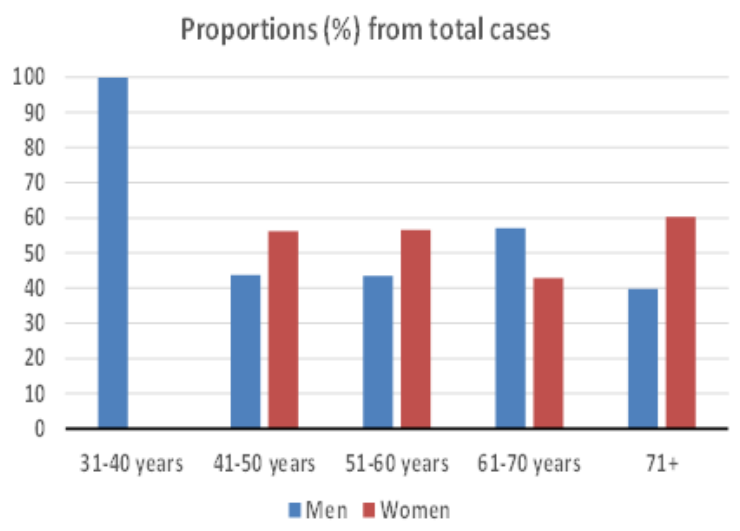

Figure 2.

Proportions from total cases of cardiovascular risk

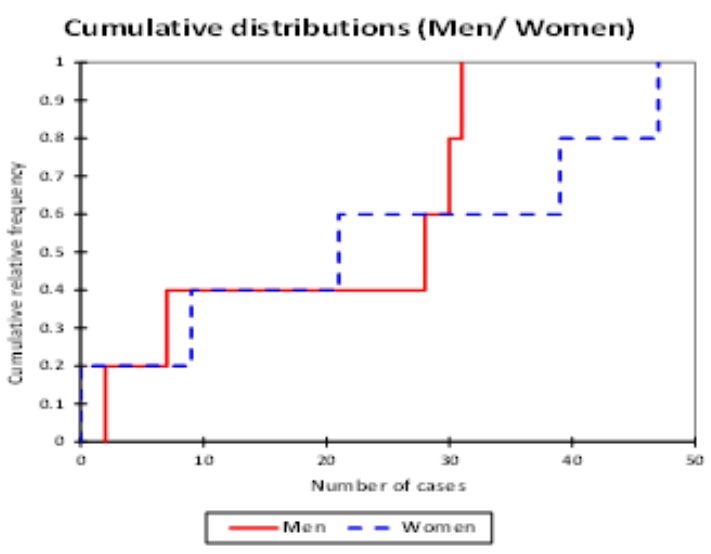

Figure 3.

Dominance diagram between gender levels: women and for the gender cardiovascular risk

\section{Dominance diagram}

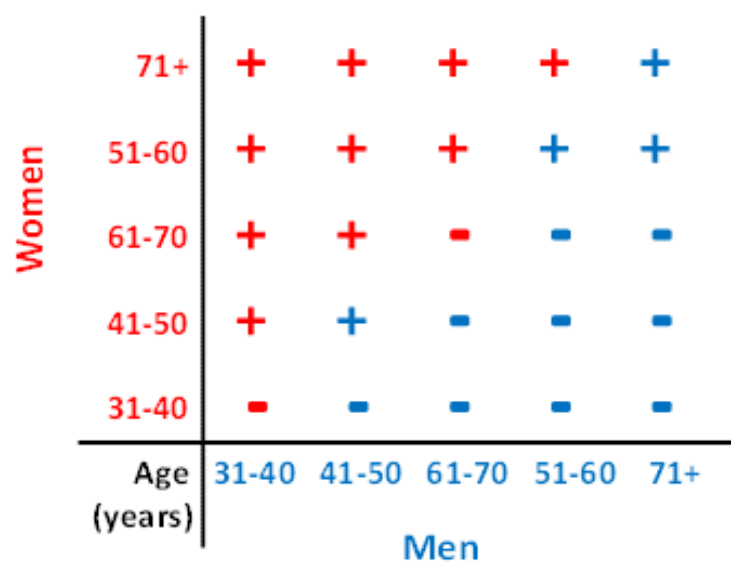

Figure 4.

Comparison of the cardiovascular risk cumulative values distribution for gender levels

The cardiovascular risk values were compared with two statistical non-parametric methods: the repeated values two samples comparison $(p=0.05)$ and the comparisons of two distributions (Kolmogorov-Smirnov test, $p=0.05)$. The experiment dealt with a low power data input and thus as stated by Lem Moyé [12] the proper statistical tests between the samples are those that compares free distributions, as previously mentioned. The repeated values non-parametric tests performed the following statistical significance values: sign test $\mathrm{p}=1.000$ and Wilcoxon signed-rank test $\mathrm{p}=0.498$. These values depict that the two samples follow the same distribution.

In order to have the complete statistical analysis, the Kolmogorov-Smirnov test was performed. The statistical significance of this test is $p=0.697$, and validates the previously mentioned results, with the conclusion that the two samples follow the same distribution. 
In this study 60 patients representing $28.03 \%$ had diabetes and another $13(6.07 \%)$ had increased basal blood glucose. Different types of obesity were present in $62(28.97 \%$ ) patients. Intriguingly, although $28.97 \%$ were obese, only $53.27 \%$ of the patients had dyslipidaemia.

For each gender factor level (women and men) as described in Figure 5, the CvR values were organized in three classes, denoting the risk intensity: AverageCvR, High-CvR and VeryHigh-CvR. Furthermore, the proportions $(\%)$ from the total number of analysed cases are presented in Figure 6. From both figures, it can be noticed that the women are exposed to $\mathrm{CvR}$ risks of average to high intensity. However, the very high CvR risk differs no more than $8 \%$; this value is 2.5 times less than the other proportion differences (Figures 7 and 8).

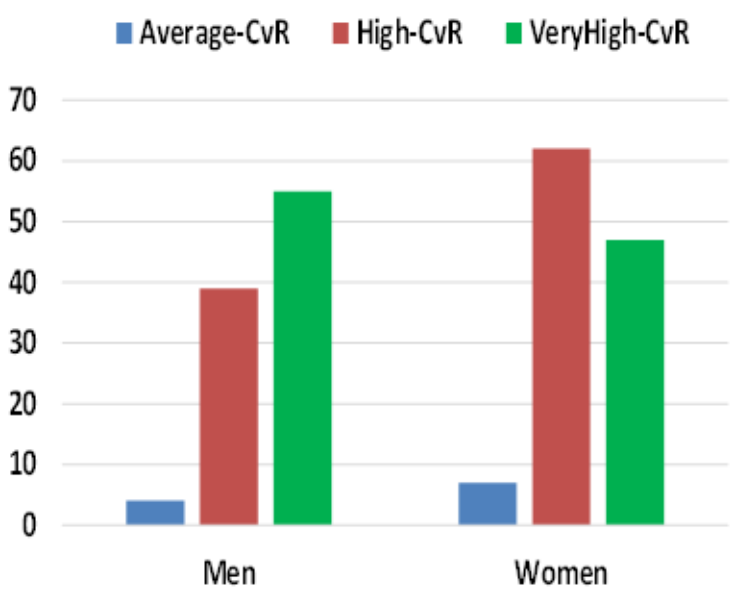

Figure 5.

Values of cardiovascular risk over the age classes for each gender

\section{Proportions (\%) from total cases}

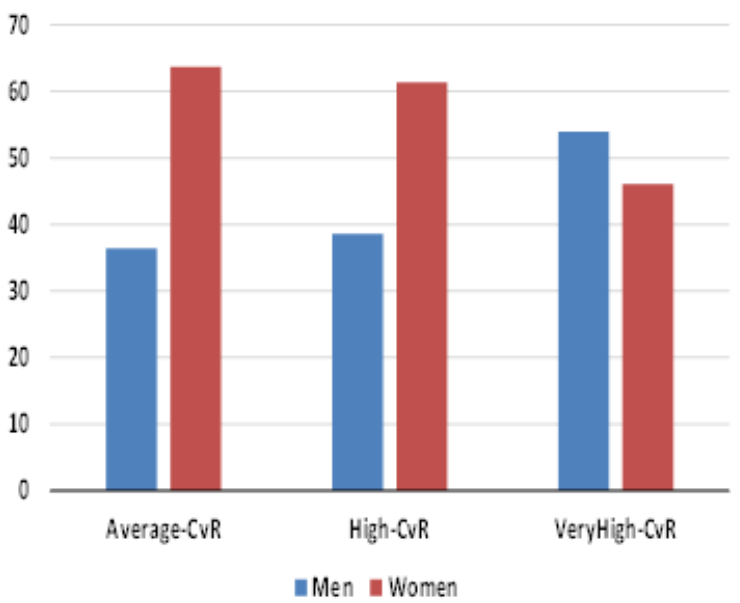

Figure 6.

Proportions from total cases of cardiovascular risk over the age classes for each gender
Dominance diagram

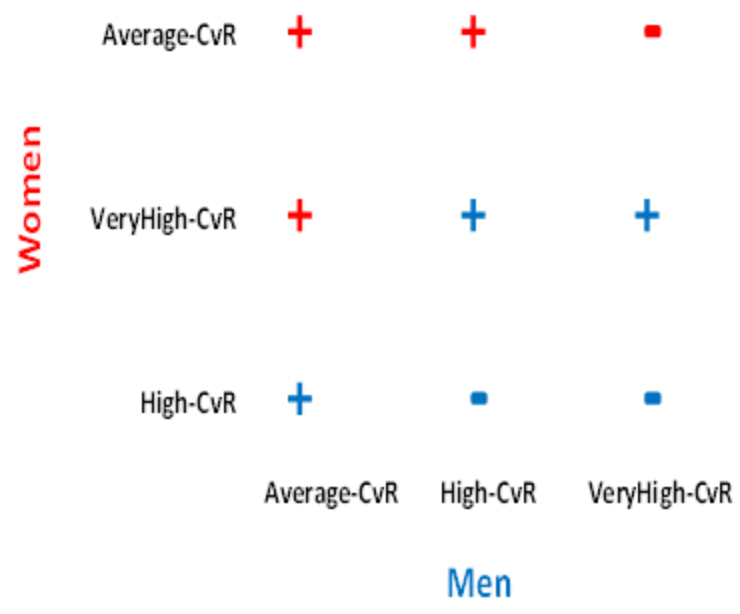

Figure 7.

Dominance diagram between genders: women and men for the cardiovascular risk values

Cumulative distributions (Men / Women)

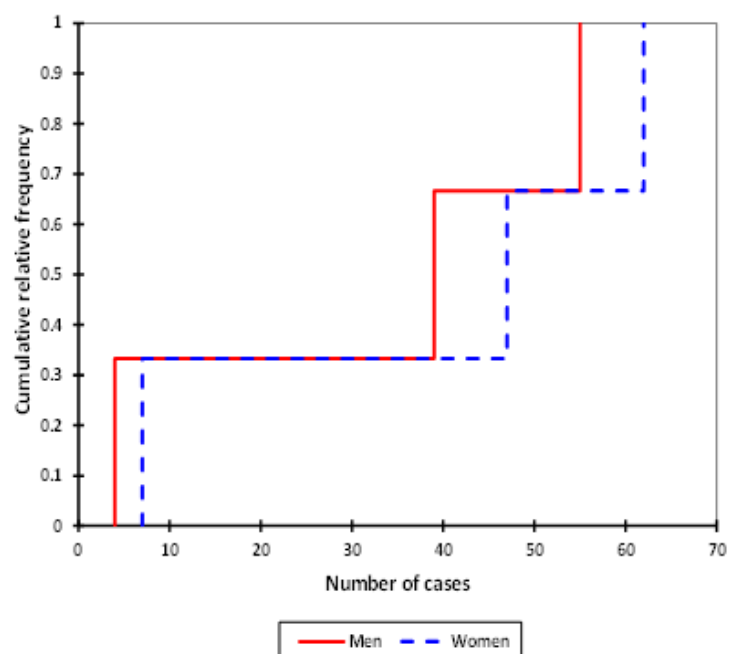

Figure 8.

Comparison of the cumulative distributions for gender levels: women and men

The CvR values were compared using two statistical non-parametric methods: the repeated values two samples comparison $(\mathrm{p}=0.05)$ and the comparisons of two distributions (Kolmogorov-Smirnov test, $\mathrm{p}=$ $0.05)$. The repeated values non-parametric tests performed the following statistical significance values: sign test $\mathrm{p}=1.000$ and Wilcoxon signed-rank test $\mathrm{p}=0.789$. These values show that the two samples follow the same distribution. In order to have the complete statistical analysis, the Kolmogorov-Smirnov test was performed. The statistical significance of this test is $p=0.976$, and validates the previously mentioned results, with the conclusion that the two samples follow the same distribution. As previously stated, the patients in this 
FARMACIA, 2020, Vol. 68, 1

study had a pre-existing cardiac disease; $64.95 \%$ had congestive heart failure and in Figure 9 we can see a distribution of the patients according to the type of cardiac disease excluding $\mathrm{CHF}$ and left ventricular failure. 179 patients had as an additional diagnostic ischaemic heart disease which represents $83.64 \%$, therefore, no clear distinction could be made as for the main cause of CHF in the patients. $22.90 \%$ had atrial fibrillation, which, if not efficiently treated with anticoagulant therapy, increases cardio-embolic risk, especially in patients with HBP, heart failure or left ventricular failure. In this study 9 patients $(4.2 \%)$ had prior myocardial infarction and 14 patients $(6.54 \%)$ undergone a myocardial revascularization through coronary artery bypass graft or stent implanted. $6.07 \%$ (13 patients) had peripheral arterial disease and 4.2\% had diabetic nephropathy or chronic renal disease. 22 patients (10.28\%) had undergone a stroke in their life (Figure 9).

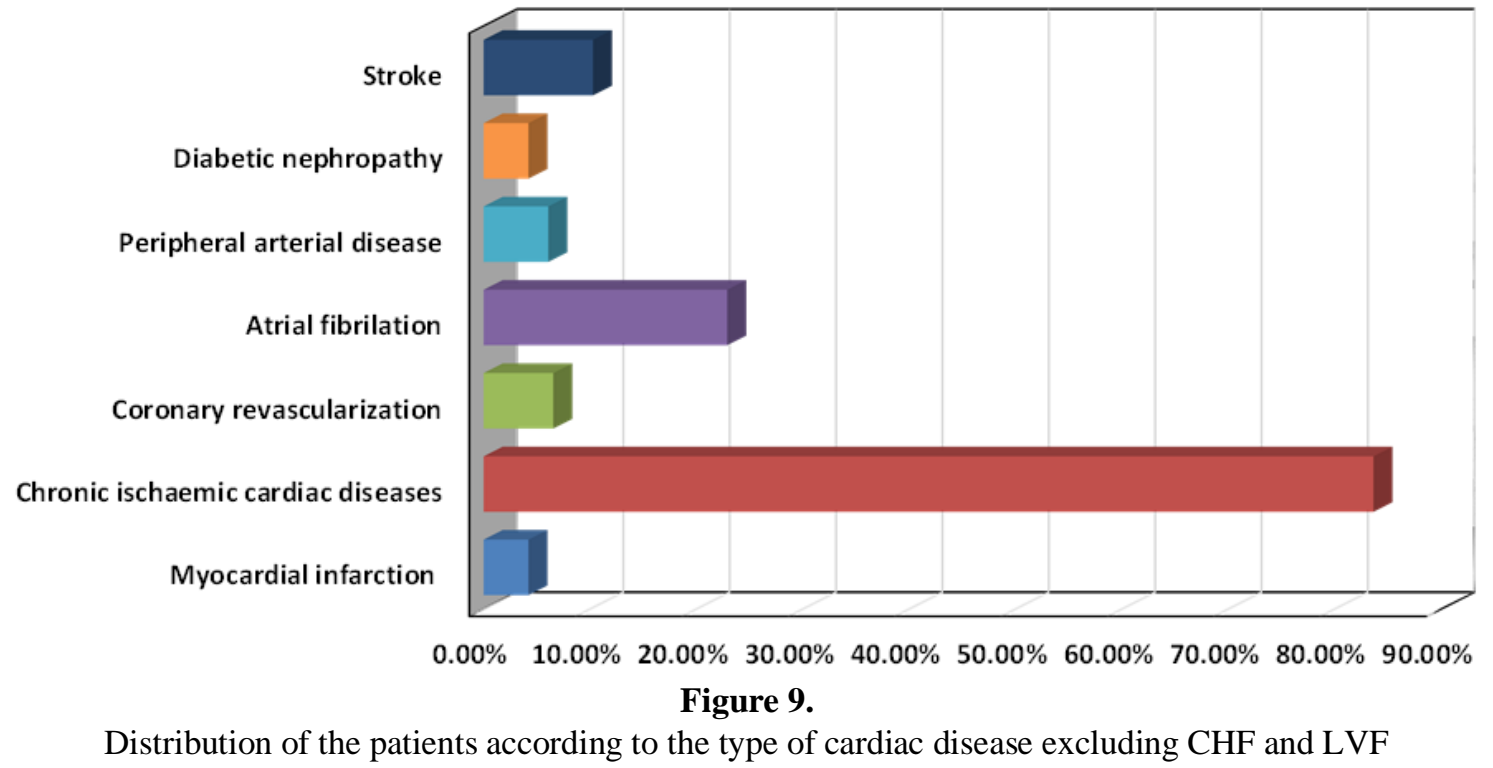

Regarding ACE-Is administered during hospitalization and recommended upon check out, we found that the most common substance was perindopril (172 patients $80.37 \%)$, followed by ramipril $(12.15 \%-26$ patients). Zofenopril was given to 7 patients (3.27\%), captopril to $2.8 \%-6$ patients, enalapril to 1 patient $(0.47 \%)$ and lisinopril to 2 patients $(0.93 \%)$.

$43.45 \%$ (93 patients) received ACE-I and a thiazide diuretic in fixed dosage and $16.82 \%$ (36 patients) received ACE-I, diuretic and calcium channel blockers. These drugs in fixed dosage increase patient adherence to treatment and their prescription is according to current guidelines recommendation.

In addition to ACE-I, 77 patients $(35.98 \%)$ received other diuretics (then thiazides) to reduce symptoms and signs of congestion in heart failure. $76.64 \%$ (164 patients) were administered beta blockers associated, 50 patients $(15.89 \%)$ were treated calcium channel blockers. Alpha adrenolytics were associated in 44 patients $(20.56 \%)$. 4 patients $(1.86 \%)$ received besides ACE-I therapy, ARBs. This combination is contraindicated according to PRAC. These 4 patients with symptomatic CHF had uncontrolled blood pressure in spite of antihypertensive therapy, therefore the ACE-I/ARBs combination was chosen. It is worth underlining that these patients didn't have diabetes with diabetic nephropathy or any renal damage, renal function being well monitored and the therapy well tolerated. $3.7 \%$ (7 patients) had persistent dry cough, which prompted switching the ACE-I with ARBs. The cough stopped soon after. 21 patients $(9.81 \%)$ were hospitalised the second time that year and 8 patients $(3.73 \%)$ had 3 hospitalisations. Figure 10 shows the distribution according to hospitalisations in 2018 .

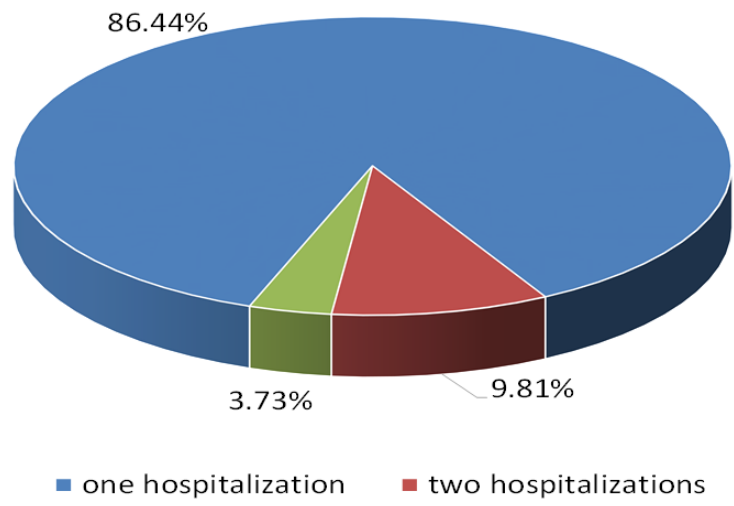

Figure 10.

Patient distribution according to hospitalisation in 2018

83.64\% (179 patients) had an improved condition upon being released from the hospital (Figure 11). 


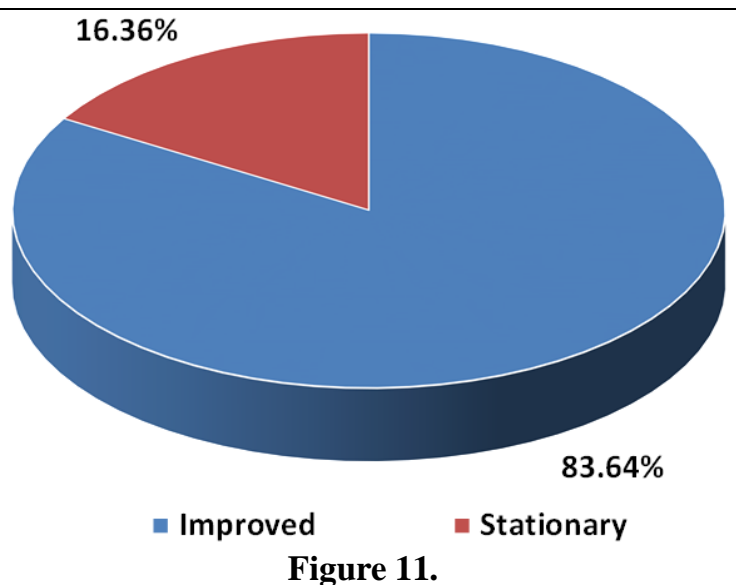

Patient distribution according to check-out status

These patients achieved a better control of blood pressure values and significant reduction in symptoms and the rest of the patients $(16.36 \%)$ were stationary upon release with a mild improvement of symptoms. HBP and its complications are a real public health issue and Romania, according to different studies, is among the countries in which blood pressure is insufficiently controlled, especially in patients with high cardiovascular risk, therefore the risk of death by fatal cardiovascular events is high. The treatment of HBP is an essential factor in preventing morbidity and mortality by cardiac diseases. ACE-I have several side effects: low blood pressure, dry cough, hyperkalaemia, rashes, angioedema, dysgeusia, granulocytopaenia, nausea, etc.

The demographic profile of patients with these diagnostics is: woman, rural environment, around 65 years old. According to the study, $54.21 \%$ were female, $56.07 \%$ were from rural environments and the average age was 65.28 years with the youngest being 38 and the oldest 87 . Most patients (78) were above the age of 71 . Regarding the global cardiovascular risk calculated using the SCORE diagram, the patients had a high cardiovascular risk (47.19\%) and very high (47.66\%) which shows a risk of death at 10 years bigger or equal to $5 \%$ and $10 \%$ respectively. $53.27 \%$ of the patients had dyslipidaemia, $28.97 \%$ obesity and $28.03 \%$ had diabetes. $64.95 \%$ had congestive heart failure and $35.05 \%$ left ventricular failure. $83.64 \%$ had also chronic ischaemic cardiac diseases, $22.9 \%$ atrial fibrillation, $10.28 \%$ stroke and $6.54 \%$ suffered coronary revascularization.

ESC 2018 guide for managing HBP recommends double or triple therapy in the same formulation for efficient reduction of blood pressure values and increasing the treatment adherence. Therefore, $43.45 \%$ had ACE-I and a thiazide diuretic in fixed dosage and $16.82 \%$ received ACE-I and thiazide diuretic and calcium channel blockers. The most commonly used ACE-I was Perindopril (82.71\%) followed by Ramipril (12.15\%) and Zofenopril (3.27\%). Regarding associating ACE-I with other drug classes, the most commonly used were diuretics (35.89\%) and beta blockers (76.64\%). 4 patients (1.86\%) received ACE-I and ARBs; these patients had symptomatic $\mathrm{CHF}$ with uncontrolled BP in spite of adequate therapy; their renal function was monitored and the therapy was well received.

\section{Conclusions}

ACE-I reduced the number of hospitalisations as the majority of the patients did not require an additional hospital visit during the same year. Most of the patients had an improved status upon check-out, therefore we can conclude that ACE-I therapy and the associated treatment reduced clinical symptoms.

During hospitalisation, most patients tolerated the therapy without side effects, except 7 patients $(3.7 \%)$ which developed dry persistent cough, therefore the ACE-I were replaced with ARBs.

\section{Conflict of interest}

The authors declare no conflict of interest.

\section{References}

1. Tripathi KD, Essentials of Medical Pharmacology, $7^{\text {th }}$ Edition, 2013; 495-561.

2. The Task Force for the management of arterial hypertension of the European Society of Cardiology (ESC) and the European Society of Hypertension (ESH), 2018 $\mathrm{ESC} / \mathrm{ESH}$ Guidelines for the management of arterial hypertension, 10-44.

3. Batel-Marques F, Mendes D, Alves C, Penedones A, Dias P, Martins A, Santiago LM, Fontes-Ribero C, Caramona M, Macedo T, Pharmacovigilance in Portugal: Activity of the Central Pharmacovigilance Unit. Acta Med Port., 2015; 28(2): 222-232.

4. Duque GS, Silva DA, Albuquerque FN, Schneider FN, Gimenez A, Pozzan R, Rocha RM, Albuquerque DC, Influence of Angiotensin-Converting-Enzyme Gene Polymorphism on Echocardiographic data of patients with ischemic heart failure. Aeq Bras Cardiol., 2016; 107(5): 446-454.

5. Suciu L, Cristescu C, Tomescu M, Balaș M, Mureșan R, Vlaia V, Voicu M, Suciu M, Grădinaru R, Vlaia L, Drăgănescu D, The impact of hypertension and associated comorbidities on quality of life assessment questionnaire SF-36 V2. Farmacia, 2013; 61(3): 503-517.

6. James MR, Lionel DL, Timothy GM, Albert F, A Textbook of Clinical Pharmacologyand Therapeutics, $5^{\text {th }}$ edition, 2008; 187-189.

7. Cristea AN, Pharmacology compendium, Editura Medicală, Bucharest, 2006; 449-452, (available in Romanian).

8. Cristea AN, Clinical Pharmacy, Editura Medicală, Bucharest, 2006; 70-74, (available in Romanian).

9. Sasu D, Active therapy on renin angiotensin-aldosterone system in arterial hypertension. Med Cour., 2012; 2(326): 47-51.

10. Blanaid MH, Filion KB, Yin H, Sakr L, Udell JA, Azoulay L, Angiotensin converting enzyme inhibitors and risk of lung cancer: population based cohort study. BMJ., 2018; 363: 1-8. 
11. Law MR, Wald NJ, Morris JK, Jordan JE, Value of low dose combination treatment with blood pressure lowering drugs: analysis of 354 randomised trials. BMJ., 2003; 326: 1427-1431.

12. Moyé L, Statistical Methods for Cardiovascular Researchers. Circ Res., 2016; 118(3): 439-453.

13. Morogovan C, Ghibu S, Juncan AM, Rus LL, Butucă A, Vonica L, Mureșan A, Moș L, Gligor F, Olah NK, Nutrivigilence: a new activity in the field of dietary supplements. Farmacia, 2019; 67(3): 537-544.

14. Crişan $\mathrm{O}$, Good pharmacy practice in the context of cross-border healthcare. Farmacia, 2017; 65(2): 138142.

15. Fried LF, Emanuele N, Zhang JH, Brophy M, Conner TA, Duckworth W, Leehey DJ, McCullough PA, O'Connor T, Palevsky PM, Reilly RF, Seliger SL, Warren SR, Watnick S, Peduzzi P, Guarino P, Combined angiotensin inhibition for the treatment of diabetic nephropathy. NEngl J Med., 2013; 369(20): 1892-1903.

16. Parving HH, Brenner BM, McMurray JJ, Dick de Zeeuw MD, Steven MH, Solomon SD, Chatuverdi N, Persoon F, Desai AS, Nicolaides M, Richard A, Xiang $\mathrm{Z}$, Brunel P, Pfeffer MA, Cardiorenal end points in a trial of aliskiren for type 2 diabetes. $N$ Engl J Med., 2012; 367(6): 2204-2213.
17. Țica OA, Țica O, Antal L, Hatos A, Popescu MI, PanteaStoian A, Bratu OG, Găman MA, Pițuru SM, Diaconu CC, Modern oral anticoagulant treatment in patients with atrial fibrillation and heart failure: insights from the clinical practice. Farmacia, 2018; 66(6): 972-976.

18. Makani H, Bangalore S, Desouza KA, Shah A, Messerli $\mathrm{FH}$, Efficacy and safety of dual blockade of the reninangiotensin system: meta-analysis of randomised trials. BMJ., 2013; 346: f360: 1-15.

19. SEPAR study analysis, 2017; http://insp.gov.ro, (available in Romanian).

20. Moisa C, Vlad AM, Teușdea A, Cadar O, Hoaghia MA, Stan RL, Tăerel A, Jurca C, Vicaș LG, Randomized evaluation on the consumption of antibiotics in community pharmacies. Farmacia, 2018; 66(6): 10811090.

21. Pharmacovigilance Risk Assessment Committee (PRAC): 26 - 29 November 2018, available at: www.ema.europa.eu/en.

22. Yusuf S, Teo KK, Pogue J, Dyal L, Copland I, Dagenais G, Sleight P, Anderson C, Telmisartan, ramipril, or both in patients at high risk for vascular events. $N$ Engl J Med., 2008; 358(15): 1547-1559. 